\title{
Stability of fatty acid composition in seal blubber during long-term storage
}

\author{
Ylva Lind ${ }^{1, *}$, Britt-Marie Bäcklin ${ }^{1}$, Karl Lundström ${ }^{2}$, Suzanne M. Budge ${ }^{3}$, \\ Michael Walton ${ }^{4}$, Olle Karlsson ${ }^{1}$ \\ ${ }^{1}$ Department of Contaminant Research, Swedish Museum of Natural History, PO Box 50007, 104 05 Stockholm, Sweden \\ ${ }^{2}$ Department of Aquatic Resources, Swedish University of Agricultural Sciences, Turistgatan 5, 45330 Lysekil, Sweden \\ ${ }^{3}$ Canadian Institute of Fisheries Technology, Dalhousie University, Halifax, Nova Scotia B3J 2X4, Canada \\ ${ }^{4}$ School of Biology, University of St Andrews, St Andrews KY16 8LB, UK
}

\begin{abstract}
This study was performed to evaluate the stability of the fatty acid (FA) composition of blubber from Baltic grey seals Halichoerus grypus archived at $-25^{\circ} \mathrm{C}$ in the Swedish Environmental Specimen Bank (SESB). Possible alterations of FA compositions with storage time and temperature were evaluated. Blubber from 5 seals was kept at $+2^{\circ} \mathrm{C}$ and at $-20^{\circ} \mathrm{C}$ and sampled for up to $6 \mathrm{mo}$ and $33 \mathrm{mo}$, respectively. Furthermore, FA profile stability was evaluated in blubber stored in the SESB for 4 and 6 yr. This was done by re-sampling and re-analyzing blubber samples from SESB. In both parts of the study, a principal component analysis was performed on 48 FAs comprising 98 to $99 \%$ of the total FAs in blubber of Baltic grey seals. We found no indication of a critically altered FA composition, neither in blubber stored at $+2^{\circ} \mathrm{C}$ for 6 mo nor in blubber stored at $-20^{\circ} \mathrm{C}$ for $33 \mathrm{mo}$. The re-analysis of samples stored in SESB for $\sim 4$ to $6 \mathrm{yr}$ only differed for a few FAs in some samples. The most remarkable differences were a slight increase in some long-chain unsaturated FAs (18:2n-6, 20:3n-3, 20:4n-3, 22:4n-3). As an increase in long-chain polyunsaturated FAs due to storage is highly unlikely, we believe that this is probably more due to the sampling technique than to a critically altered FA composition due to storage. Our results suggest that archived seal blubber may be safely used in retrospective analyses of diet using an FA signature analysis technique.
\end{abstract}

KEY WORDS: Fatty acid composition $\cdot$ Long-term storage $\cdot$ Blubber $\cdot$ Grey seal $\cdot$ Baltic Sea

\section{INTRODUCTION}

In recent years, an increasing number of studies have used fatty acid (FA) signature analysis of blubber in seals to examine foraging ecology and diet (Käkelä 1996, Käkelä \& Hyvärinen 1998, Bradshaw et al. 2003, Walton \& Pomeroy 2003, Iverson et al. 2004, Arnould et al. 2005, Budge et al. 2006, Smith \& Worthy 2006, Beck et al. 2007, Ridoux et al. 2007). The underlying principle of FA signature analysis is that the chemical structure of many FAs is not altered as they pass through food webs; therefore, the FA composition in the blubber of a seal is strongly influ- enced by the FA composition of the diet of the seal. Thus, the FA composition of blubber can reveal variation in the diets between different populations (Käkelä 1996, Walton et al. 2000, Samuel \& Worthy 2004).

The Swedish Environmental Specimen Bank (SESB) at the Swedish Museum of Natural History (SMNH) has a large collection of tissues of seals from the Baltic Sea. Thorough records of health status, nutritional status, age, and other biological parameters from post mortem examination are available for these seals that have been collected for more than 30 yr. During this time, extensive ecological alter- 
ations due to anthropogenic activities have taken place in the Baltic Sea. This includes severe environmental pollution and overfishing that have altered populations of both predators and prey species (Bergman \& Olsson 1985, Olsson et al. 1992, Thurow 1997, Harding \& Härkönen 1999, Österblom et al. 2006, 2007, Casini et al. 2008, 2010).

Retrospective analyses of the FA proportions in archived blubber might give insight into variation in the diet of Baltic seals over time, which could be useful in analyzing food-web changes in the Baltic Sea. The presumption for this is that the FA structures in the archived blubber are intact or that at least that the relative amounts of FA have not changed.

As FAs in tissues are usually reported as the relative proportions of the individual FA by weight (wt\%), oxidation and other degradation processes that influence different FAs to different extents might eventually lead to a change in the proportions of the different FAs. This process would disrupt the original FA composition of the blubber and make it impossible to use FAs to examine diet variation.

The present study was undertaken to: (1) investigate possible deterioration of FAs in seal blubber at 2 different storage temperatures and (2) investigate the stability of FA profiles in seal blubber stored in the SESB at $-25^{\circ} \mathrm{C}$ for 4 and $6 \mathrm{yr}$. The purpose was to reveal the potential to use archived blubber in retrospective studies of diet in seals.

\section{MATERIALS AND METHODS}

Baltic grey seals Halichoerus grypus that were either by-caught in fishing gear or found dead on the shore have been sent to the SMNH for examination since the 1970s. Most of the seals arrived at the $\mathrm{SMNH}$ in a fresh or, sometimes, frozen state. During necropsy, samples of bones, teeth, muscle, internal organs, and blubber were taken for the SESB. All sampled organs including blubber samples (100 to $200 \mathrm{~g}$ ) were weighed and wrapped in aluminum foil and stored separately in sealed plastic bags at $-25^{\circ} \mathrm{C}$. Since 2003 , separate blubber samples for FA analyses have been taken in connection with the necropsy of the seals. These samples were taken with a $6 \mathrm{~mm}$ biopsy punch (pfm - Produkte für die Medizin) through the skin and the entire blubber layer on the intact seal and put in a $10 \mathrm{ml}$ glass tube in chloroform:methanol solution $(2: 1$, with $0.05 \%$ by weight 2,6 di-tert-butyl-4-methyl-phenol [BHT] added) and stored at $-20^{\circ} \mathrm{C}$ until analyzed for FA composition.

\section{Expt 1: stability of FAs under different storage conditions}

In order to test the stability of FAs under different storage conditions, pieces of blubber of roughly 10 by $10 \mathrm{~cm} \mathrm{(200} \mathrm{to} 400 \mathrm{~g})$ with intact skin and visible muscle layer were taken from 5 seals. The seals used in this part of the study were by-caught in fishing gear, arrived at SMNH within a few days after death and were not frozen before necropsy. The seals were kept at $+2^{\circ} \mathrm{C}$ until necropsy that took place 4 to $10 \mathrm{~d}$ after death. At necropsy, the seals were estimated to be in good condition, i.e. fur and skin still intact and no odor of decay. Blubber samples were taken in connection with necropsy and stored in open plastic bags at $+2^{\circ} \mathrm{C}$ and at $-20^{\circ} \mathrm{C}$. Small subsamples (100 mg) were taken at different times according to Table 1. The first of these subsamples, referred to as the 0 -sample, was taken during the necropsy. At all sampling occasions except the 0 -sample, 2 subsamples were taken, one at the edge (E: edge samples) and one at least $2 \mathrm{~cm}$ from the edge (C: core samples) of the stored pieces of blubber. This was done in order to determine whether there was an edge effect on the FA profile, i.e. deterioration due to a larger exposure to air at the edge of the blubber. For each subsample, care was taken to sample the whole blubber layer from skin to muscle. The skin and traces of muscle were present on all blubber samples, and

Table 1. Halichoerus grypus. Storage temperature and storage time (days) for blubber samples $(10 \times 10 \mathrm{~cm}, 200$ to $400 \mathrm{~g}$ ) from 5 grey seals (A to E). Two subsamples (edge and core) were taken at each temperature and time. A time-0 subsample was taken during the necropsy of the seal (not shown in the table)

\begin{tabular}{|lrr|}
\hline Seal ID & Days at $2^{\circ} \mathrm{C}$ & Days at $-20^{\circ} \mathrm{C}$ \\
\hline A & 31 & 31 \\
& 201 & 201 \\
& & 390 \\
B & 166 & 1006 \\
& & 166 \\
& & 356 \\
C & 31 & 971 \\
& 181 & 31 \\
& & 181 \\
& & 369 \\
D & 69 & 986 \\
& & 69 \\
& & 189 \\
E & 156 & 873 \\
& & 156 \\
\hline
\end{tabular}


these parts were included in the subsamples. The blubber subsamples were immediately put in $10 \mathrm{ml}$ glass tubes with chloroform: methanol solution and treated in the same manner as samples taken from whole seals at necropsy. The blubber samples that had been stored at $+2{ }^{\circ} \mathrm{C}$ for 69 to $201 \mathrm{~d}$ separated into a liquid (oily) fraction and a solid fraction. In this case, sub-sampling was performed in a slightly different way. Instead of taking a core and an edge sample, subsamples were taken as follows: (1) a few $\mathrm{ml}$ of the liquid fraction was poured into a $10 \mathrm{ml}$ test tube and frozen until analyzed for FA without the chloroform: methanol solution; (2) approximately $100 \mathrm{mg}$ of the solid fraction was sampled and treated in the same manner as the other blubber subsamples. This blubber was clearly in an advanced state of decay but was included in the analysis for comparison to FA profiles in fresh and less decayed blubber.

\section{Expt 2: stability of FAs during prolonged storage}

This part of the study was done to test the stability of FAs in seal blubber under the storage conditions used in SESB. Blubber from 10 seals (a to j) was used in this experiment. They had earlier been sampled and analyzed for FA composition in connection with the necropsy as described above. After approximately 4 yr of storage in SESB, the blubber was sampled again and re-analyzed for FA composition. From all portions of blubber, 2 subsamples were taken: one at the edge (coded as 2E) and one at least $2 \mathrm{~cm}$ from the edge (coded as 2C), through the whole piece of blubber as described above. As a part of another, ongoing study, 6 of these blubber samples (b, c, d, f, $h, j)$ were again subsampled and analyzed for FA, approximately $6 \mathrm{yr}$ after the original analysis. This sample was taken at least $2 \mathrm{~cm}$ from the edge of the blubber. The results from this third sampling and FA analysis were also included in the present study. Samples are indicated by the seal ID letter and subsample code.

\section{FA analysis}

The FA profiles used in Expt 1 were analyzed at the Sea Mammal Research Unit (SMRU), University of St Andrews, Scotland, UK, and at the Canadian Institute of Fisheries Technology (CIFT), Dalhousie University, Halifax, Nova Scotia, Canada. In Expt 2, the original analyses and the analyses made after approximately $4 \mathrm{yr}$ were done at SMRU while the analyses made after approximately 6 yr of storage were made at CIFT. The same method for FA analyses is used at the 2 laboratories and has been described elsewhere (Budge \& Iverson 2003, Walton \& Pomeroy 2003, Budge et al. 2006) FAs are expressed as \% of total FAs by weight and are designated by shorthand International Union of Pure and Applied Chemistry (IUPAC) nomenclature of carbon chain length: number of double bonds and location $(n-x)$ of the double bond nearest the terminal methyl group.

\section{Statistics}

We used principal component analysis (PCA) to transform the large number of partly correlated original variables (i.e. the FAs in this case) into a small number of orthogonal (uncorrelated) variables, which are essentially linear combinations of the original variables. The first component described the highest proportion of the total variance, and gradually smaller proportions of the variance were represented by each consecutive component. Determination of the number of significant components in the model was made by cross validation. Explained variation $\left(R^{2}\right)$ and predicted variation $\left(Q^{2}\right)$ were calculated and the criteria for a good model were set to $R^{2}$ $>0.7$ and $Q^{2}>0.4$, according to Lundstedt et al. (1998). In Expt 1, a redundancy analysis (RDA) was performed with storage time (days), temperature, and type of sample (original sample, edge, core, liquid oil, and solid, coded as dummy variables) as explanatory variables. In Expt 2, partial RDA was performed with original, edge, and core as dummycoded explanatory variables and seal ID as a dummycoded covariable to account for within-individual differences and to study the effect of sample type. Inter-individual differences were assessed using seal ID as an explanatory variable and sample type as the covariable to account for their effect. Statistical significance of the explanatory variables was examined using Monte Carlo permutation tests ( $\mathrm{n}=1999)$.

As the individual FA compositions are presented as percentage by weight (mass percentages) of the total FAs, the data were transformed by arcsinetransformation of the square root of the proportions. In the PCA, data were also mean centered and scaled to unit variance after transformation.

Statistical software used was Statistica (StatSoft, www.statsoft.com), Simca-P+ (12.0.1.0), and CANOCO 4.5 (ter Braak \& Šmilauer 2002). Significance level was set to $\mathrm{p}<0.05$. 
Table 2. Halichoerus grypus. Concentration (weight \%) of 48 fatty acids (FAs) together contributing 98 to $99 \%$ of the total FAs in blubber from Baltic grey seals. The order of the FAs is according to their retention time from the gas chromatograph column. The table shows the median and minimum (min) and maximum (max) values for all analyses of grey seal blubber. Minor FAs include 4 unidentified FAs and FAs that were individually present below $0.1 \%$ by weight

\begin{tabular}{|c|c|c|c|}
\hline Fatty acid & Median & Min & Max \\
\hline $14: 0$ & 2.90 & 1.64 & 4.05 \\
\hline $14: 1 n-9$ & 0.09 & 0.02 & 0.35 \\
\hline $14: 1 \mathrm{n}-7$ & 0.07 & 0.04 & 0.12 \\
\hline $14: 1 \mathrm{n}-5$ & 0.78 & 0.25 & 1.62 \\
\hline i-15:0 & 0.21 & 0.13 & 0.33 \\
\hline ai-15:0 & 0.09 & 0.03 & 0.14 \\
\hline $15: 0$ & 0.38 & 0.22 & 0.46 \\
\hline $16: 0$ & 9.08 & 4.50 & 15.6 \\
\hline 16:1n-11 & 0.15 & 0.01 & 0.34 \\
\hline $16: 1 n-9$ & 0.64 & 0.43 & 1.05 \\
\hline $16: 1 n-7$ & 15.2 & 8.34 & 23.8 \\
\hline $16: 1 n-5$ & 0.32 & 0.19 & 0.58 \\
\hline $\mathrm{i}-17: 0$ & 0.22 & 0.04 & 0.68 \\
\hline ai-17:0 & 0.18 & 0.06 & 0.56 \\
\hline $16: 2 n-4$ & 0.23 & 0.11 & 0.56 \\
\hline $17: 0$ & 0.18 & 0.07 & 0.30 \\
\hline $16: 3 n-4$ & 0.14 & 0.05 & 0.54 \\
\hline $17: 1 \mathrm{n}-\mathrm{x}$ & 0.53 & 0.23 & 0.78 \\
\hline $16: 4 n-1$ & 0.04 & 0 & 0.22 \\
\hline $16: 4 n-3$ & 0.08 & 0 & 0.23 \\
\hline $18: 0$ & 0.95 & 0.54 & 1.86 \\
\hline 18:1n-11 & 0.10 & 0 & 0.56 \\
\hline $18: 1 n-9$ & 24.6 & 17.6 & 31.6 \\
\hline $18: 1 n-7$ & 4.65 & 2.94 & 6.93 \\
\hline $18: 1 n-5$ & 0.25 & 0.19 & 0.35 \\
\hline $18: 2 n-6$ & 4.42 & 1.72 & 6.11 \\
\hline $18: 2 n-4$ & 0.08 & 0.04 & 0.36 \\
\hline $18: 3 n-6$ & 0.13 & 0.07 & 0.33 \\
\hline $18: 3 n-4$ & 0.17 & 0.05 & 0.34 \\
\hline $18: 3 n-3$ & 2.10 & 1.04 & 2.67 \\
\hline $18: 3 n-1$ & 0.07 & 0.02 & 0.21 \\
\hline $18: 4 n-3$ & 1.57 & 0.38 & 2.05 \\
\hline 20:1n-11 & 0.08 & 0.02 & 0.70 \\
\hline 20:1n-9 & 0.78 & 0.48 & 1.51 \\
\hline $20: 1 n-7$ & 0.30 & 0.15 & 1.54 \\
\hline $20: 2 n-6$ & 0.57 & 0.30 & 1.37 \\
\hline $20: 3 n-6$ & 0.15 & 0.08 & 0.38 \\
\hline $20: 4 n-6$ & 0.67 & 0.40 & 1.79 \\
\hline $20: 3 n-3$ & 0.37 & 0.14 & 0.99 \\
\hline $20: 4 n-3$ & 0.98 & 0.52 & 2.56 \\
\hline $20: 5 n-3$ & 4.37 & 2.24 & 6.05 \\
\hline $22: 1 n-9$ & 0.04 & 0 & 0.20 \\
\hline $21: 5 n-3$ & 0.24 & 0.16 & 0.37 \\
\hline $22: 4 n-6$ & 0.18 & 0.11 & 0.84 \\
\hline $22: 5 n-6$ & 0.30 & 0.12 & 0.51 \\
\hline $22: 4 n-3$ & 0.38 & 0.04 & 1.94 \\
\hline $22: 5 n-3$ & 4.30 & 3.21 & 6.11 \\
\hline $22: 6 n-3$ & 12.9 & 9.31 & 18.3 \\
\hline Minor FAs & 1.32 & 1.02 & 1.98 \\
\hline
\end{tabular}

\section{RESULTS}

Sixty-one identified and 4 unidentified FAs were analyzed and quantified. FAs present in individual concentrations $\leq 0.1 \%$ in all samples were summarized together with the 4 unidentified FAs and referred to as minor FAs. The 48 identified FAs constituting 98 to $99 \%$ of total FAs in blubber from Baltic grey seals that were used in the statistical analyses in the present study are shown in Table 2 .

\section{Expt 1: stability of FAs under different storage conditions}

In the PCA performed on this dataset, the results from all subsamples of the blubber sample from each individual seal were used. PCA was carried out using 48 identified FAs + the minor FA group and storage time (days) as continuous variables, and storage temperature and individual seal as categorical variables; this resulted in a model with 5 significant components $\left(R^{2} \mathrm{X}=0.88\right.$ and $\left.Q^{2} \mathrm{X}=0.78\right)$. The PC1-axis accounted for $41.6 \%$ of the variation and the PC2axis accounted for $22.7 \%$. A clear separation of the data into 5 clusters could be attributed to the individual seal, while no observable separation according to treatment or storage time of the blubber could be detected (Fig. 1). The RDA analysis with storage conditions and time as explanatory variables indicated that these variables accounted for $7.9 \%$ of the total variation and that no statistical significant differences could be attributed to these variables $(\mathrm{p}=0.77$, $F=0.77$ ). If only time was used as an explanatory variable, it explained $1.9 \%$ of the total variation in the dataset.

\section{Expt 2: stability of FAs during long time storage}

The PCA shown in Fig. 2 revealed that for 6 of the blubber samples $(a, c, d, e, i, j)$, the initial analysis and the second analysis carried out after 4 yr of storage (edge and core) were grouped together. A third analysis made after $6 \mathrm{yr}$ of storage was available for 6 of the samples (b, c, d, f, h, j; Fig. 2). However, for 2 of the blubber samples $(b, g)$, the consecutive analyses made on the same blubber sample were not grouped together, and for both of these samples it was the initial analysis that deviated from the repeated analyses (Fig. 2). To illustrate how the actual FA profiles differed in the case where all analyses of the same seal were grouped together and in the case where the 
a
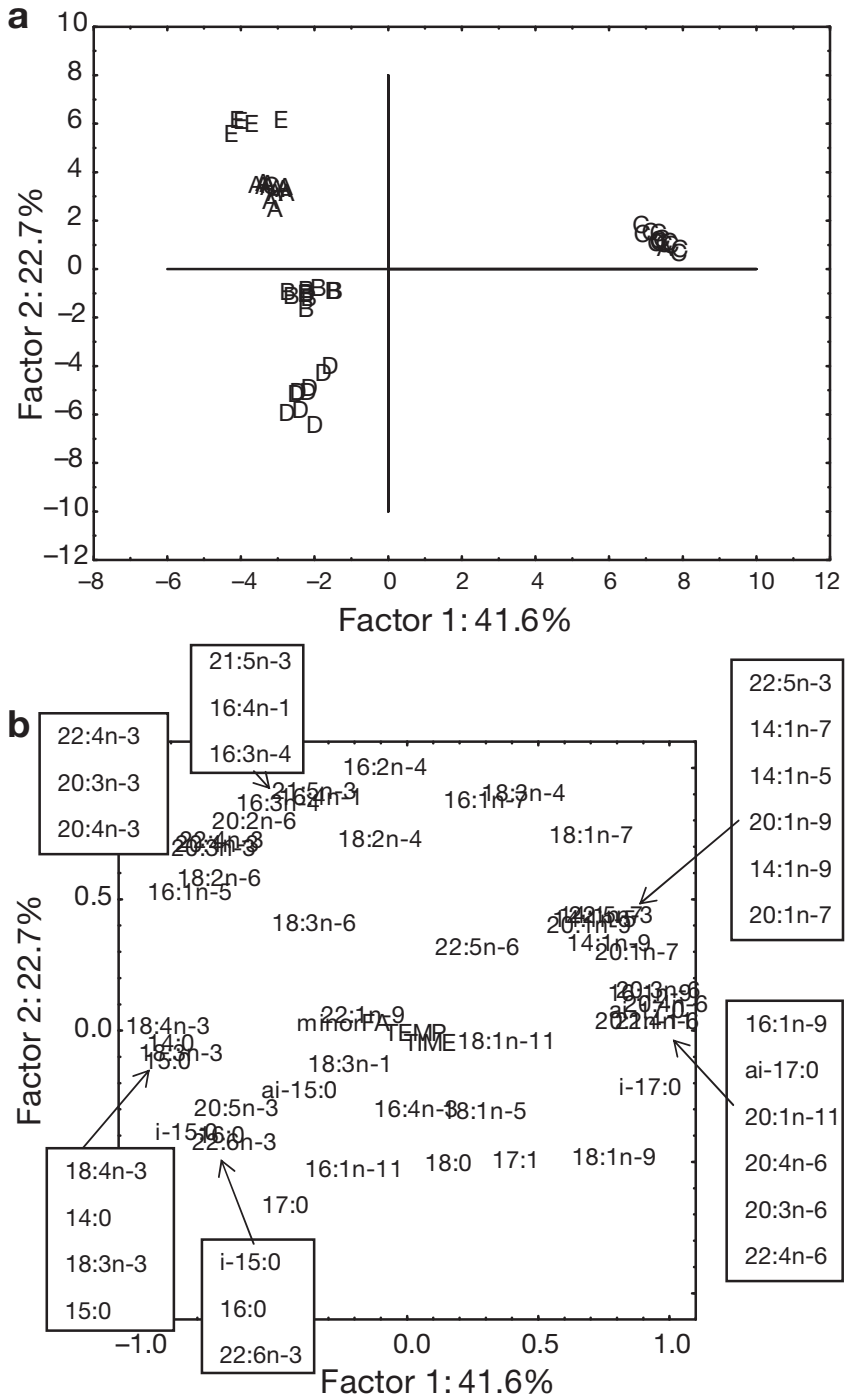

Fig. 1. Halichoerus grypus, Expt 1. (a) Score scatter plot and (b) loading scatter plot (below) of fatty acids (FAs) in blubber from 5 Baltic grey seals (A to E) stored at $+2^{\circ} \mathrm{C}$ and at $-20^{\circ} \mathrm{C}$ (TEMP) and sampled at different storage times according to Table 1 (TIME)

first analysis differed from the subsequent analyses, the FA profile of seal c (grouped together) and seal b (initial analysis deviates) are shown (Figs. 3 \& 4, respectively). The most notable differences are that for seal $b, 20: 4 n-6$ and 22:6n-3 had decreased between the initial analysis and the analyses performed 4 yr later. However, 22:6n-3 again increased in the analyses made after another $2 \mathrm{yr}$ of storage, i.e. a total storage time of $6 \mathrm{yr}$ after the initial analysis. The FAs 18:2n-6, 20:3n-3, 20:4n-3, and 22:4n-3 had increased between the first analysis and the analyses performed 4 and 6 yr later. The same pattern was seen for seal $g$ (not shown). For seal g, no analysis carried out after 6 yr was available.
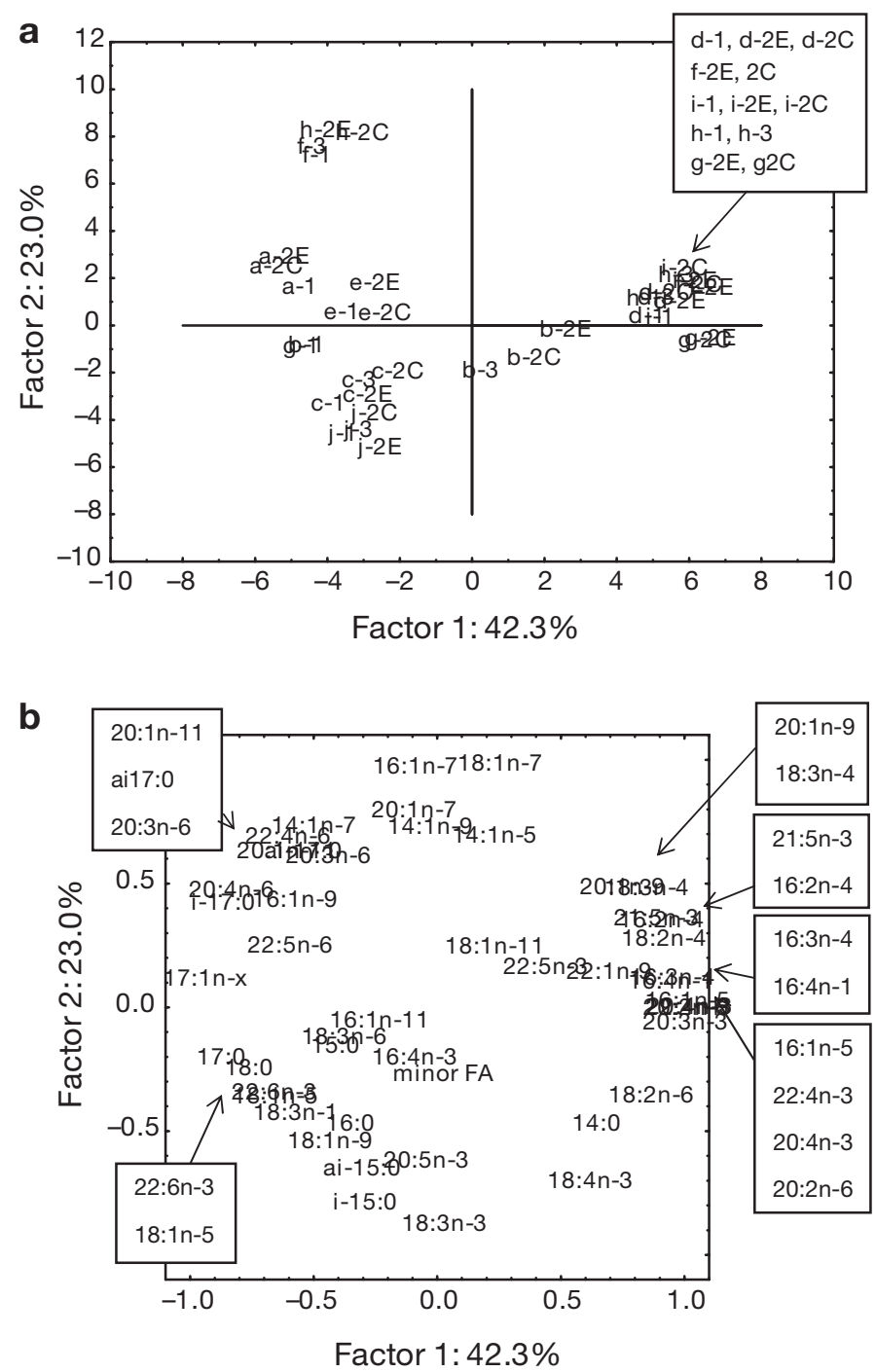

Fig. 2. Halichoerus grypus, Expt 2. (a) Score scatter plot and (b) loading plot of fatty acid (FA) profiles of blubber from 10 Baltic grey seals (a to j). FAs were analyzed on subsamples of blubber taken in connection with necropsy (1) and on blubber subsamples taken after $4 \mathrm{yr}$ of storage in the Swedish Environmental Specimen Bank (2). For the latter, the letters $\mathrm{E}$ and $\mathrm{C}$ denote edge and core samples, respectively. For seals b, c, d, f, h, and j, a third analysis of FAs taken after 6 yr of storage was available (3)

The partial RDA analysis with sample types (original, edge, core) as explanatory variables and seal ID as the covariable showed that $9.2 \%(\mathrm{p}=0.006, F=$ 2.93) of the variation in the dataset could be attributed to type of sample, after accounting for the effect of seal ID. When seal ID was used as the explanatory variable and sample types as covariables, we found that $59 \%$ of the variation ( $\mathrm{p}=0.0005, F=3.78$ ) could be explained by variations in FAs between individual seals. 


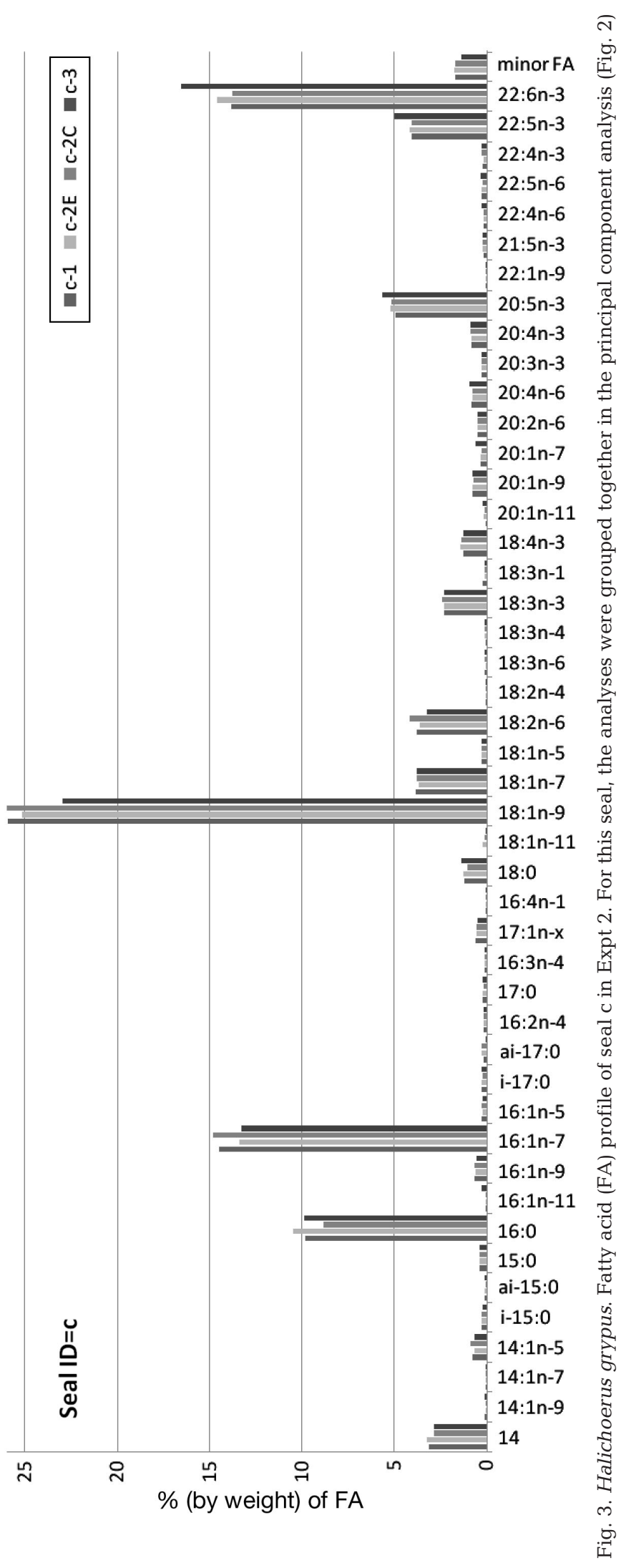

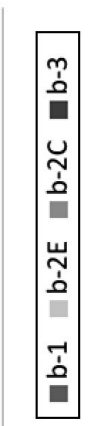

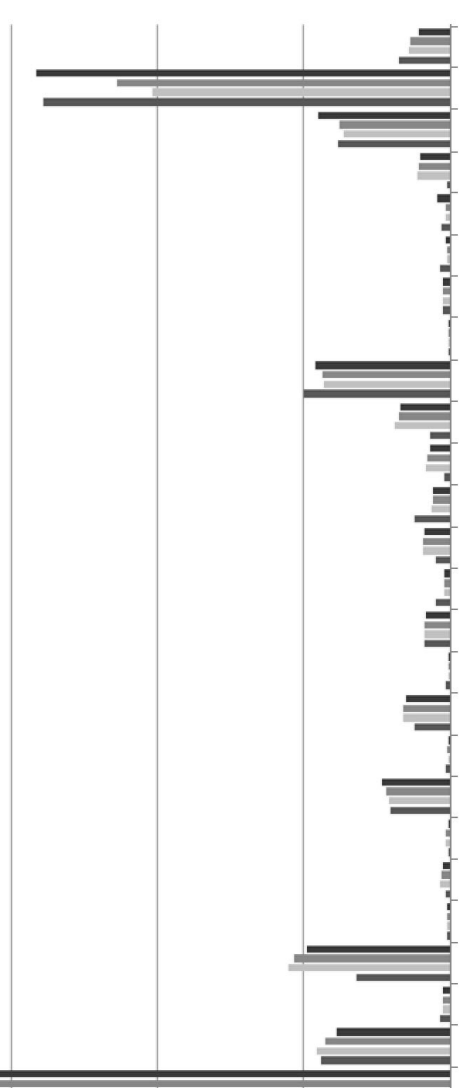

minor FA

$22: 6 n-3$

$22: 5 n-3$

$22: 4 n-3$

$22: 5 n-6$

$22: 4 n-6$

21:5n-3

$22: 1 n-9$

20:5n-3

$20: 4 n-3$

$20: 3 n-3$

$20: 4 n-6$

$20: 2 n-6$

$20: 1 n-7$

$20: 1 n-9$

20:1n-11 ซृ

$18: 4 n-3$

$18: 3 n-1$ के के

18:3n-3 $\quad \overrightarrow{0} \mathrm{c}$

$18: 3 n-4$ )

$18.3 n-6$ 요

$18: 2 n-4$. क

$18.2 n-2 \sum^{2} \delta$

18:1n-5 चृ च

$18: 1 n-7$ न

in in

18:1n-11

18:0

เั है

16:4n-1 ㅅำ

17:1n-x 䒕, 先

$16: 3 n-4$ Iบ

$17: 0$

도 농

$16: 2 n-4$ नี

ai-17:0 \& थ

i-17:0 อัจ

$16: 1 n-5$

16:1n-9

$16: 1 \mathrm{n}-11$ 近要

16:0 .

15:0

ai-15:0

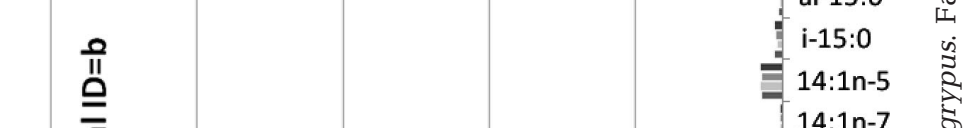

壳

离

14:1n-7

$14: 1 n-9$

14

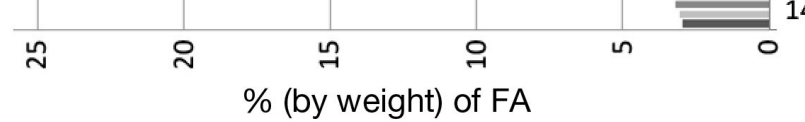

$\%$ (by weight) of FA 


\section{DISCUSSION}

The aim of the present study was to determine whether the FA profiles of stored seal blubber remained constant with time and whether frozen blubber, archived under the conditions employed in SESB, maintained a constant FA profile over time, allowing their use in retrospective studies of diet. Because of this, our focus was on identifying patterns among the FAs that could indicate possible differences in decomposition of individual FAs due to time and temperature. This could change the relative FA composition of the blubber and make it unsuitable for use in studies where relative FA composition is crucial.

In Expt 1, no evidence was found to indicate that the handling of the blubber or the storage time had changed the FA composition of the blubber in a substantial manner. The 5 clusters found in the PCA could be attributed to the FA composition of the blubber of the individual seals in this experiment. Certainly, in this case differences in FA composition between individuals were far greater than any changes due to storage time or temperature within a blubber sample from a single individual.

In Expt 2, the stability of FAs in seal blubber stored under the conditions used in SESB was evaluated. In this case, the blubber had been packed and stored under the standard conditions of the SESB. For 6 out of 10 samples, the re-analyses were grouped together with the original analysis, indicating that there had not been any substantial change in the FAs for these samples. However, 4 samples did not group together, indicating that there were differences between the different analyses for these samples. Further inspection of the results for 2 of these samples ( $f$ and h) revealed a likely mix-up between samples. The reason for this conclusion is that $\mathrm{f}-1$ and $\mathrm{f}-3$ (original and third analysis of seal $\mathrm{f}$ ) are grouped together with $\mathrm{h}$ $2 \mathrm{E}$ and $\mathrm{h}-2 \mathrm{C}$ (second analysis of seal $\mathrm{h}$, edge and core) and h-1 and h-3 are grouped together with f-2E and $\mathrm{f}-2 \mathrm{C}$.

Nevertheless, for 2 samples, seal $\mathrm{b}$ and seal $g$, the initial analyses deviated from the subsequent analyses. A closer look at the individual FA profiles of these 2 seals showed that for a small number of FAs, a difference was observed between the original analysis and the subsequent analyses. FAs 20:4n-6 and 22:6n-3 had decreased and 18:2n-6, 20:3n-3, $20: 4 n-3$, and $22: 4 n-3$ had increased between the first and second analysis. This indicates that for these samples, there was a change in the FA composition of the blubber between the initial and the subsequent analyses. FAs 20:4n-6 and 22:6n-3 are highly unsaturated and should be more readily susceptible to degradation, so a decrease in proportions due to storage would be expected. However, the increases in proportions of $18: 2 n-6,20: 3 n-3,20: 4 n-3$, and 22:4n-3 that also are highly unsaturated cannot be explained by degradation effects. In the FA profile of seal b (Fig. 4), the FA $22: 4 n-3$ is present in very low amounts in the original analysis but has increased substantially in the re-analyses 4 yr later and again in the same amount after another $2 \mathrm{yr}$ of storage. As this is a long-chain, highly unsaturated FA, it is not likely that it should increase due to storage. Moreover, the long-chain, highly unsaturated FA 22:6n-3 that decreased between the original and second analysis had again increased to the same amount in the third analysis performed after another $2 \mathrm{yr}$ of storage. Therefore, a more likely explanation for the discrepancy between the original and subsequent analyses of the blubber for 2 of the samples ( $b$ and $g$ ) is that identical subsamples of the blubber had not been collected on the different sampling occasions and that it is probably the original subsample that was somehow not collected in the same manner as the subsequent samples. It is known that many FAs can be stratified in blubber from marine mammals (Best et al. 2003, Krahn et al. 2004, Smith \& Worthy 2006, Strandberg et al. 2008, 2011). If the whole blubber was not sampled or if a small part of the sampled blubber was lost in connection to the sampling, this might result in differences in the FA profiles.

The stored blubber samples from both the first and second experiments were visibly altered both in color and in consistency. Blubber stored at $-20^{\circ} \mathrm{C}$ in contact with air for $3 \mathrm{yr}$ was yellower in color compared to fresh blubber. The blubber stored at $+2{ }^{\circ} \mathrm{C}$ for the longest time (156 to $201 \mathrm{~d}$ ) had even separated into an oily fraction and a non-oily fraction and emanated an unpleasant smell. Decomposition had undoubtedly taken place, as could be detected by the changes in color, texture, and odor of the samples. In Expt 1, it was obvious that this had not changed the relative FA composition of the blubber samples in a conclusive way and that the individual differences between the seals were larger than the effect due to storage.

Seal blubber consists largely ( 70 to $80 \%$ ) of triacylglycerols, i.e. glycerol molecules with 3 FAs. Besides triacylglycerols, seal blubber also contains water, proteins, vitamins, antioxidants, and phospholipids. Vitamin $\mathrm{E}$ is an important antioxidant for protecting unsaturated FAs (Frankel 1984, Ricciarelli et al. 2001), and several studies have analyzed Vitamin E 
levels in blubber of seals (Engelhardt et al. 1975, Schweigert et al. 1990, Mazzaro et al. 2003, Nyman et al. 2003, Routti et al. 2005, 2010, Brunborg et al. 2006). Generally, the variation is large and dependent on species and geographical location (Käkelä et al. 1997, Nyman et al. 2003). Vitamin E may play a role in the relative stability of FAs found in the present study and may be a topic for future research.

There are also earlier studies that indicate similar results as found in the present study. A study on blubber from harbor porpoises Phocoena phocoena, stored at room temperature for $8 \mathrm{~d}$, at 7 to $8.5^{\circ} \mathrm{C}$ for up to $19 \mathrm{~d}$, and at $-20^{\circ} \mathrm{C}$ for up to $566 \mathrm{~d}$, indicated that no consistent patterns regarding changes in FA composition attributed to storage could be detected (Learmonth 2006). Also in that study, it was concluded that there was little evidence for lipid oxidation in stored blubber. Two studies on human adipose tissue stored as microbiopsies with little contact with air for up to $6 \mathrm{yr}$ at room temperature $\left(20^{\circ} \mathrm{C}\right)$ and for up to $11 \mathrm{yr}$ at $-80^{\circ} \mathrm{C}$ indicated that the FA composition had remained constant, even at room temperature (Deslypere et al. 1993, Katan et al. 2003). The conclusion from these studies was that it was possible to obtain reliable results for FA composition on stored biopsies of human adipose tissue.

The results from our Expt 1 indicate that storage conditions of blubber samples that are to be used in studies where the FA composition is crucial might not be as important as previously thought. The FA composition of the individual seals was clearly visible even in the most decayed blubber. The results from the experiment with re-analyses of blubber from the SESB (Expt 2) are more inconclusive. There was undoubtedly a difference between the first analyses and the 2 second analyses for a few blubber samples, indicating that there could have been a storage effect on the FA composition of the blubber. However, as we did not see a similar pattern in any of the samples in Expt 1 where the blubber was visibly much more affected by storage time and conditions, we believe that the observed discrepancy in the results for some of the samples in the second study is more likely due to the sampling technique. This conclusion is also supported by the increase of a number of polyunsaturated FAs after 4 and 6 yr of storage in the samples where a discrepancy was found between the initial analysis and the repeated analyses.

The results from the present study indicate that it is possible to use archived blubber in studies on FAs. It also shows that the sampling techniques of the blubber that is to be used in analysis of FA profiles are very crucial and should be used with the utmost care.
Acknowledgements. We thank the anonymous reviewers for valuable comments on the manuscript, and Eva Eklöf for excellent technical assistance. Funding was provided by Magnus Bergwalls Foundation (MBS) and the Swedish Environmental Protection Agency (SEPA).

\section{LITERATURE CITED}

> Arnould JPY, Nelson MM, Nichols PD, Oosthuizen WH (2005) Variation in the fatty acid composition of blubber in Cape fur seals (Arctocephalus pusillus pusillus) and the implications for dietary interpretation. J Comp Physiol B Biochem Syst Environ Physiol 175:285-295

> Beck CA, Iverson SJ, Bowen DW, Blanchard W (2007) Sex differences in grey seal diet reflect seasonal variation in foraging behaviour and reproductive expenditure: evidence from quantitative fatty acid signature analysis. J Anim Ecol 76:490-502

Bergman A, Olsson M (1985) Pathology of Baltic grey seal and ringed seal females with special references to adrenocortical hyperplasia: Is environmental pollution the cause of a widely distributed disease syndrome? Finn Game Res 44:47-62

Best NJ, Bradshaw CJA, Hindell MA, Nichols PD (2003) Vertical stratification of fatty acids in the blubber of southern elephant seals (Mirounga leonina): implications for diet analysis. Comp Biochem Physiol Part B Biochem Mol Biol 134:253-263

> Bradshaw CJA, Hindell MA, Best NJ, Phillips KL, Wilson G, Nichols PD (2003) You are what you eat: describing the foraging ecology of southern elephant seals (Mirounga leonina) using blubber fatty acids. Proc R Soc Lond B Biol Sci 270:1283-1292

Brunborg LA, Julshamn K, Nortvedt R, Froyland L (2006) Nutritional composition of blubber and meat of hooded seal (Cystophora cristata) and harp seal (Phagophilus groenlandicus) from Greenland. Food Chem 96:524-531

Budge SM, Iverson SJ (2003) Quantitative analysis of fatty acid precursors in marine samples. J Lipid Res 44: 1802-1807

> Budge SM, Iverson SJ, Koopman HN (2006) Studying trophic ecology in marine ecosystems using fatty acids: a primer on analysis and interpretation. Mar Mamm Sci 22: 759-801

Casini M, Lövgren J, Hjelm J, Cardinale M, Molinero JC, Kornilovs G (2008) Multi-level trophic cascades in a heavily exploited open marine ecosystem. Proc R Soc Lond B Biol Sci 275:1793-1801

Casini M, Bartolino V, Molinero JC, Kornilovs G (2010) Linking fisheries, trophic interactions and climate: threshold dynamics drive herring Clupea harengus growth in the central Baltic Sea. Mar Ecol Prog Ser 413: 241-252

> Deslypere JP, Van de Bovenkamp P, Harryvan JL, Katan M (1993) Stability of n-3 fatty acids in human fat tissue aspirates during storage. Am J Clin Nutr 57:884-888

> Engelhardt FR, Geraci JR, Walker BL (1975) Tocopherol distribution in the harp seal, Pagophilus groenlandicus. Comp Biochem Physiol B Comp Biochem 52:561-562

> Frankel E (1984) Lipid oxidation: mechanisms, products and biological significance. J Am Oil Chem Soc 61: 1908-1917

Harding KC, Härkönen TJ (1999) Development in the Baltic grey seal (Halichoerus grypus) and ringed seal (Phoca 
hispida) populations during the 20th century. Ambio 28: 619-625

Iverson SJ, Field C, Bowen DW, Blanchard W (2004) Quantitative fatty acid signature analysis: a new method of estimating predator diets. Ecol Monogr 74:211-235

Käkelä R (1996) Fatty acid composition in subspecies of ringed seal (Phoca hispida) and several semiaquatic mammals: site specific and dietary differences. $\mathrm{PhD}$ thesis, University of Joensuu

Käkelä R, Hyvärinen H (1998) Composition of polyunsaturated fatty acids in the liver of freshwater and marine ringed seals (Phoca hispida ssp.) differs largely due to the diet of the seals. Comp Biochem Physiol Part B Biochem Mol Biol 120:231-237

Käkelä R, Hyvärinen H, Käkelä A (1997) Vitamins A(1) (retinol), A(2) (3,4-didehydroretinol) and E (alpha-tocopherol) in the liver and blubber of lacustrine and marine ringed seals (Phoca hispida sp.). Comp Biochem Physiol Part B Biochem Mol Biol 116:27-33

Katan MB, Harryvan JL, van de Bovenkamp P (2003) n-3 fatty acids in human fat tissue aspirates are stable for up to 6 y. Eur J Clin Nutr 57:816-818

Krahn MM, Herman DP, Ylitalo GM, Sloan CA and others (2004) Stratification of lipids, fatty acids and organochlorine contaminants in blubber of white whales and killer whales. J Cetacean Res Manag 6:175-189

Learmonth JA (2006) Life history and fatty acid analysis of harbour porpoises (Phocoena phocoena) from Scottish waters. PhD thesis, University of Aberdeen

Lundstedt T, Seifer E, Abramo L, Thelin B, Nyström Å, Pettersen J, Bergman R (1998) Experimental design and optimization. Chemometr Intell Lab 42:3-40

Mazzaro LM, Dunn LJ, Furr HC, Clark RM (2003) Serum retinol, alpha-tocopherol, and lipids in four species of adult captive pinnipeds. Zoo Biol 22:83-96

Nyman M, Bergknut M, Fant ML, Raunio H and others (2003) Contaminant exposure and effects in Baltic ringed and grey seals as assessed by biomarkers. Mar Environ Res 55:73-99

Olsson M, Andersson Ö, Bergman Å, Blomkvist G, Frank A, Rappe C (1992) Contaminants and diseases in seals from Swedish waters. Ambio 21:561-562

Österblom H, Casini M, Olsson O, Bignert A (2006) Fish, seabirds and trophic cascades in the Baltic Sea. Mar Ecol Prog Ser 323:233-238

Österblom H, Hansson S, Larsson U, Hjerne O, Wulff F, Elmgren R, Folke C (2007) Human-induced trophic cascades and ecological regime shifts in the Baltic Sea. Ecosystems 10:877-889

Editorial responsibility: Hans-Heinrich Janssen, Oldendorf/Luhe, Germany
Ricciarelli R, Zingg JM, Azzi A (2001) Vitamin E: protective role of a Janus molecule. FASEB J 15:2314-2325

- Ridoux V, Spitz J, Vincent C, Walton MJ (2007) Grey seal diet at the southern limit of its European distribution: combining dietary analyses and fatty acid profiles. J Mar Biol Assoc UK 87:255-264

Routti H, Nyman M, Bäckman C, Koistinen J, Helle E (2005) Accumulation of dietary organochlorines and vitamins in Baltic seals. Mar Environ Res 60:267-287

Routti H, Jenssen BM, Lydersen C, Bäckman C and others (2010) Hormone, vitamin and contaminant status during the moulting/fasting period in ringed seals (Pusa [Phoca] hispida) from Svalbard. Comp Biochem Physiol Part A Mol Integr Physiol 155:70-76

Samuel AM, Worthy GAJ (2004) Variability in fatty acid composition of bottlenose dolphin (Tursiops truncatus) blubber as a function of body site, season, and reproductive state. Can J Zool 82:1933-1942

> Schweigert FJ, Stobo WT, Zucker H (1990) Vitamin E and fatty acids in the grey seal (Halichoerus grypus). J Comp Physiol B 159:649-654

> Smith HR, Worthy GAJ (2006) Stratification and intra-and inter-specific differences in fatty acid composition of common dolphin (Delphinus sp.) blubber: implications for dietary analysis. Comp Biochem Physiol B Biochem Syst Environ Physiol 143:486-499

> Strandberg U, Käkelä A, Lydersen C, Kovacs KM, GrahlNielsen O, Käkelä R (2008) Stratification, composition, and function of marine mammal blubber: the ecology of fatty acids in marine mammals. Physiol Biochem Zool 81: 473-485

> Strandberg U, Sipilä T, Koskela J, Kunnasranta M, Käkelä R (2011) Vertical fatty acid profiles in blubber of a freshwater ringed seal-comparison to a marine relative. J Exp Mar Biol Ecol 407:256-265

ter Braak CJF, Šmilauer P (2002) CANOCO reference manual and CanoDraw for Windows user's guide: software for canonical community ordination (version 4.5). Microcomputer Power, Ithaca, NY

Thurow F (1997) Estimation of total fish biomass in the Baltic Sea during the 20th century. ICES J Mar Sci 54:444-461

$>$ Walton M, Pomeroy P (2003) Use of blubber fatty acid profiles to detect inter-annual variations in the diet of grey seals Halichoerus grypus. Mar Ecol Prog Ser 248: 257-266

> Walton MJ, Henderson RJ, Pomeroy PP (2000) Use of blubber fatty acid profiles to distinguish dietary differences between grey seals Halichoerus grypus from two UK breeding colonies. Mar Ecol Prog Ser 193:201-208

Submitted: October 5, 2011; Accepted: April 17, 2012

Proofs received from author(s): June 28, 2012 